\title{
The what, how and why of fake news: An overview
}

\section{Greg Simons ${ }^{1}$}

Ural Federal University, Russia

IRES Institute for Russian and Eurasian Studies, Uppsala University, Sweden University of Turiba, Latvia

Andrey Manoilo

Russian Academy of Sciences (INION RAS), Russia

To cite this article: Simons, G., \& Manoilo, A. (2021). The what, how and why of fake news: An overview. World of Media. Journal of Russian Media and Journalism Studies 2. DOI: $10.30547 /$ worldofmedia.2.2021.2

\begin{abstract}
This article examines the nature of the origin, definitions and functional principles of so-called fake news - reports that are deliberately false in nature which can create a stir in society around a non-existent informational case born of the same news source. In combination with viral technologies and mechanisms of distribution in the media and social networks, fake news in modern political campaigns is becoming a dangerous tool for in uencing mass consciousness of societies. The main task of fake news in modern political campaigns and processes is interception of the political agenda, with its subsequent closure to the news feed generated by the fake news itself, as well as creation of general excitement around the given news story. This present article seeks to review and analyse the academic debates on the what (definition), how (operationalization) and why (motivation) questions pertaining to the fake news phenomena. These aspects are then combined to generate the beginnings of creating a conceptual taxonomy to understand this highly topical and emotive concept.
\end{abstract}

\section{Keywords}

Fake news, deception, perception, information war, digital journalism.

${ }^{1}$ Corresponding author:

Greg Simons, Ural Federal University, Russia; IRES Institute for Russian and Eurasian Studies, Uppsala University, Sweden; University of Turiba, Latvia. Postal address: Box 514, SE 75120 Uppsala, Sweden.

Email: gregmons@yahoo.com 


\section{Introduction}

The topic of fake news has become increasingly popular as a subject of study and an object of 'communication' in an increasingly chaotic and divided global information realm. Often, authors cite the 2016 US Presidential Election as being a milestone moment in the fake news academic debate and evaluation of its practice (Farkas \& Schou, 2018; Guess et al., 2020; Jankowski, 2018; Van Duyn \& Collier, 2019). It has been noted in critical research that 'the current media and political environment provides a fertile breeding ground for fake news' (Guo $\&$ Vargo, 2020). Fake news requires not only definition, but also classification, as well as elaboration of proprietary methodologies, which motivate studies of this phenomenon in its environment. International studies are gradually shaping certain attitude towards fake news as an object of political analysis. For instance, Pennycook, Cannon and Rand (2018) believe that fake news must be understood as a completely false content claimed to be actual, yet which is able to create an 'illusion of truth', however, featuring low level of credibility. Verstrarte, D. Bambauer and J. R. Bambauer (2017) believe that propaganda, satire, and trolling may be attributed to fake news. Drexl (2019) links the phenomenon of fake news to the politics of 'post-truth' which is disseminated by the Internet intermediaries like Facebook and Twitter. Schnellenbach (2018) suggests that people oftentimes need fake news to validate their own beliefs, assertions, and fears. This demonstrates a truly diverse academic interpretation of this contemporary hot political topic.

News and information are increasing about influencing and persuading audiences at the levels of politics (Kazun \& Kazun 2020) and international relations (Gavra \& Naumenko 2020), which can manifest as a clash of interpretations of reality by mass media outlets and audiences. At the same time, many authors claim that fake news, its dissemination in social media, and the effects spawned by the same should be controlled on the government level (Metaxa-Kakavouli \& Torres-Echeverry, 2017). There is, however, a different opinion with this regard. For example, Lima de Carvalho (2017) considers control over fake news as threatening 'freedom of liberty of expression of opinions' in the online environment. The analysis of these works shows that scientific comprehension of the fake news phenomenon is highly active, and yet at the same time largely descriptive in nature.

A critical evaluation of academic definitions shall form the basis of trying to formulate a conceptual understanding of what fake news is, how it is used and why it is used. These aspects shall be supplemented by an empirical analysis of news media narratives on the operationalisation aspects of fake news. 
Combined, these two parts shall be used in an attempt to answer the following research question. What are the informational and cognitive conditions that support a fake news environment?

After the methodology and approach is detailed for the reader, the next section of the paper engages with the role and value of information and the three domains of the human world (physical, information and cognitive). This establishes the basis and context for moving to the issue of fake news, which begins with an overview of the current state of the art academic literature concerning the definition (the what) of the concept. Then the next section involves an overview and analysis of the role and purpose of fake news (the how). Following this is the section on the academic literature on the motivations for using fake news (the why).

\section{The three domains and the information sphere}

It is necessary to understand how the physical, informational, and cognitive components of the human world inter-relate and interact with each other. Within the realm of information warfare, there are three domains to be considered: the physical domain, the information domain, and the cognitive domain (Alberts et al., 2001) ${ }^{2}$. In terms of the search for political, social or economic influence, the domain that they seek to influence is the cognitive perception of the physical one in order to enable practical operations and policy. This is the easiest domain to measure as it is a tangible one. An understanding of the reality and 'ground truth' translates into psychological or policy effectiveness and information dominance. On the intangible side, information exists and is created in the information domain. It is shared and can be subjected to manipulation, which means that the information in it may not accurately reflect the ground truth as it is a 'representation' of reality. This domain concerns the communication of information among and between the various vested actors. The information domain is subject to competition and interference from other actors present, which implies offensive and defensive dimensions to communication activities. The objective is to gain information superiority within the information domain over the adversary. The minds of the participants are found in the cognitive domain, which is 'where perceptions, awareness, understanding, beliefs, and values reside, and where, as a result of sense making, decisions are made' (Alberts et al., 2001). This is the domain in which the physical and psychological competitions are actually won or lost as it involves such crucial intangibles as

${ }^{2}$ For more details on these domains please refer to chapter two in Alberts et al., 2001. 
leadership, trust, group cohesion, level of knowledge and experience, situational awareness and public opinion. All content in this domain passes through the filtering process of human perception, therefore the objective of mass communication is to influence and persuade the collective cognitive domain.

A new conceptual framework for research on public relations, propaganda and promotional culture is in the making. This is Organised Persuasive Communication (OPC), which is 'a systematic conceptualisation of different forms of persuasive communication including categories of dialogical, nondeceptive and deceptive OPC as well as persuasion working in relation to sociopolitical, economic and physical contexts via incentivisation and coercion' (Bakir et al., 2019). However, it is necessary to add a further physical context of shaping knowledge and perception through managing the content appearing in the information domain. Bakir et al. (2019) venture as far as to state that OPC 'is essential to the exercise of power at national and global levels'. They also observe that its study within the context of the political system of liberal democracy is a 'blind spot'. Within the context of deceptive messages and communications, Freelon and Wells (2020) note that 'disinformation messages under this definition are munitions in campaigns of information warfare, nonlethal weapons intended to subdue adversaries rather than reason with them'3 Hence OPC, including disinformation is playing an increasingly active role in the field of political communication.

How does this relate to news, its conceptual values and pragmatic practice, in the wider context of political communication? Given the various conceptual and operational transformations and shifts in the idea and practice of news, there is a need to define what news is and what role its does/should play in society. This is important as the historical memory shapes our current understanding in terms of what the idealised relationships and the inter-generational links with the contemporary situation as news transforms from analogue to include digital formats. In 2001, Harcup and O'Neill concluded (with exceptions to the rule) that news stories need to have at least one of the following elements present in any given story: the power elite, celebrity, entertainment, surprise, bad news, good news, magnitude, relevance, follow-up, and editorial agenda (Harcup \& O'Neill, 2017). There is also the conceptual expectation of an independent and adversarial role, McNair (2004) defines the function of the fourth estate as being 'an independent institutional source of political and cultural power which

${ }^{3}$ Freelon and Wells (2020) avoid the term 'fake news', which they deem as a concept that is lacking theoretical relevance owing to the nature of its popular application and characterisation that stripped it of its analytical value. 
monitors and scrutinises the actions of the powerful in other spheres'. This ideal notion and practice are supported by other academics and practitioners, such as Kovach and Rosenstiel (2007). However, the traditional values of news and journalism are transforming along with the social, political and economic in which it is operating. "The era of news objectivity as "just the facts" is dead and gone. Interpretative journalism grows' (Ward, 2014). This necessitates understanding the separation and implications of commentary, opinion, analysis and facts, which is becoming increasingly blurred in an evolving information environment.

It has been noted (Bergström \& Jervelycke Belfrage, 2018) that the environment of news production and consumption is rapidly changing. The traditional news cycle that was dominated by traditional journalists and mass media outlets is now a much more complex environment that also includes citizens and non-professionals where news outlets still produce most of the news consumed, but which also circulates through social media and aggregators. Harcup and O'Neill (2017) revised their taxonomy for news, to the following order of points: exclusivity, bad news, conflict, surprise, audio-visuals, shareability, entertainment, drama, follow up, the power elite, relevance, magnitude, celebrity, good news and news organisation's agenda. However, this is not uniform and subjected to, at times, subconscious influences as cultural, historical, educational, ideological, social or economic aspects that affect the individual and/or collective cognitive realm. These differences illustrate the effects and growing influence of the digital generation and technological environment on the news value taxonomy.

Within the context of the three domains (physical, informational and cognitive), news production, communication and intent has experienced a great conceptual shift. From the idealised notion of the fourth estate, where news, journalism and mass media sought to conceptually describe the events of the physical world in such a way (with periodic connotations of 'truth' and objectivity' invoked) as the audience can create their own cognitive interpretation of those people, places and events. This has shifted, with the idea of 'interpretive journalism' that communicates a subjective representation of the physical domain through the information domain to determine how the audience forms opinions and perceptions of people, places and events in their cognitive domain.

\section{Methodology}

The approaches to textual analysis shall include content analysis (quantifications of different elements in text), argumentation analysis (the structure of argumentation used), and the qualitative analysis of ideas in the content 
(with a focus on persuasion and attraction) (Boréus \& Bergström, 2017). The combination of these approaches is expected to yield results on the ontology (what exists) and epistemology (knowledge and how we 'know' things) of reactions to academic textual depictions of the fake news, its definitions and motivations for use. The objects of study include power, persuasion, journalism, politics, identity, deception and so forth (Boréus \& Bergström, 2017). The academic texts then contextualize the relationships according to perceived and projected power in the constructed social world order of mankind where there is on the one hand the people and events of the physical domain, and on the other the information domain's representation of the physical environment intending to influence the cognitive domain of the target audience.

It is the intention of the author to use a qualitative approach to analysing the data, and given the size of the samples, to create an indicative study. The sample material collected for this chapter was found via a Google Scholar search in 2020. Search terms that were entered are: definition of fake news; role of fake news; motivations for fake news. The first 10 pages of Google Scholar search results were manually checked by the author for relevance based upon the stated criterion in the first paragraph of this section. A total of 76 articles were selected for further evaluation and analysis.

The theoretical method of analysis is based on phenomenology, which involves the 'understanding of how appearances affect consciousness prior to the attempt to conceptualise objects and events' (2011). Fake news as a concept is a construct that intends to provide meaning to the human experience. Gelman (1996) notes that 'concepts are fundamental to all of human experience. Naming objects, recognizing novel instances, generalizing from the known to the unknown, making inferences, and learning new information all make use of concepts'. Also noted by Gelman (1996), concepts should not be treated and analysed in isolation from theories, stating 'both are mental representations that give order to experience'. This represents the significance of concepts for the human experience and interpretation of the physical realm.

It is the intention of the authors to use a literature review to track and understand the evolution of meaning (both theoretically and practically) of fake news. A critical evaluation of the literature review of the current state of the art research on fake news is intended to form the basis for arriving at a tentative indicative result on identifying a conceptual taxonomy framework that can better inform and predict 'ideal' conditions for supporting fake news. It needs to consider the physical, informational and cognitive domains, including the relationships and interactions between them. 


\section{Definition of fake news (the what)}

Fake news, like other buzzwords, is semantically confusing. This confusion is contributed greatly by the evolving definition of the concept and its purpose. The problem is further amplified by the misuse of the term fake news, which is seen as being problematic as well as its practice and effects in contemporary society (Brummette et al., 2018). Initially, fake news was associated with contrived or constructed information that is a symbolic informational representation of reality, such as talk shows and satire. This then evolved to refer to the deceptive and/or manipulative use of information to mislead audiences, with implications in the field of information warfare. Currently, the shift in definition tends to signify information that contradicts the worldview and opinions of individuals or groups, such as Trump's invocation of CNN as being fake news (Holan, 2017; Simons, 2017; Waisbord, 2018). However, the idea and practice of the definitions of fake news are vastly older than the current use of this contemporary buzzword (Burkhardt, 2017; Cooke, 2020; Shu et al., 2017; Van Heekeren, 2020). While there is little new in the concept of practice, differences are found elsewhere. 'What is different is the speed, scale and massive proliferation and consumption of false information disseminated on dominant digital platforms' (Waisbord, 2018). This opening hints at the complexity associated with the evolving manner of defining and using the concept of fake news, which leads to some scholars (Freelon \& Wells, 2020) to declare that the concept of fake news lacks any analytical value. However, such dilemmas and problems have not stopped various scholars from trying to find a viable definition.

Some of the definitions of fake news contain various assumptions and taken for granted systems of norms and values inherent in the system of liberal democracy. A binary constructed reality can be attempted by academic and journalistic attempts to delineate fact from fake. This is labelled as being problematic as attempts to categorise, classify and demarcate 'fake' and 'true' is a deeply subjective and political practice in its own right (Farkas \& Schou, 2018). At times, these definitions can be uncritical of any possible flaws in the system.

We define 'fake news' to be fabricated information that mimics news media content in form but not in organisational process or intent. Fake news outlets, in turn, lack the news media's editorial norms and processes for ensuring the accuracy and credibility of information. Fake news overlaps with other information disorders, such as misinformation (false or misleading information) and disinformation (false information that is purposely spread to deceive people) (Lazer et al., 2018). 
This definition is based upon the actor, which excludes news media, and the intent of the actor communicating. Other scholars, such as Albright (2017) are in partial agreement with the above, where 'factual reporting can be displaced with "alternative" narratives. The use of the "fake news" label to denote organisational untrustworthiness is a related concern, as it portrays media watchdogs as entities that operate to deliberately misinform'. Such understandings and definitions deny the significant changes occurring in news media, detailed extensively by scholars such as Waisbord (2018), Bergström and Jervelycke Belfrage (2018). The editorial norms and processes that the authors refer to have been in the process of breaking down, to the point where scholars such as Ward (2014) no longer speak of truth and objectivity in journalism, but 'interpretation.' This definition offers an uncomplicated informational representation of the physical domain, where 'good' and 'bad' actors are seemingly easily delineated.

Mould (2018) uses the Collins Dictionary to define fake news as 'false, often sensational, information disseminated under the guise of news reporting. $<\ldots>$ Fake news, either as a statement of fact or as an accusation, has been inescapable this year [2017], contributing to the undermining of society's trust in news reporting'. However, importantly, it was also determined what should not be considered fake news. This includes: 1 ) unintentional reporting mistakes; 2) rumours that do not originate from a particular article; 3) conspiracy theories; 4) satire; 5) false statements by politicians; and 6) reports that are slanted or misleading, but are not completely false (Mould, 2018). There are some parallels in other attempts to define fake news: 'encompasses the observation that, in social media, a certain kind of "news" is spread much more successfully than others, and that this "news" is typically extremely one-sided (hyper-partisan), inflammatory, emotional, and often riddled with untruths" (Potthast et al., 2017). At its most simplistic level, fake news is defined as being 'a news article that is intentionally or verifiably false' (Shu et al., 2017) or 'viral posts based on fictitious accounts made to look like news reports' (Tandoc et al., 2018). Van Heekeren (2020) offers the definition of 'the intentional invention and publication of false information presented as news and designed to deceive for financial or political gain'. There is a number of commonalities observable in fake news research.

Some of those commonalities include the elements of facticity and intention. Whereas satire uses selective facts in a diverting (humorous) format, fake news uses information in a focusing format (on a particular person, issue, etc.). This leads to intention, satire is intended to entertain a target audience, fake news intends to mislead and/or manipulate behaviour within the context and frame 
of falsified reality. This necessitates the audience to perceive the fake as real to physically spread the fake news and creator's cognitive intent (Brennan, 2017; Gelfert, 2018; Ha et al., 2019; Rini, 2017; Tandoc et al., 2018). In addition, fake news often contains affective content as a deliberate means to emotionally prime and mobilise the target audience (Bakir \& McStay, 2018). These different elements identified in the definition and description of fake news are intended to serve the role and purpose of fake news, its operational execution that is aimed at realising different individual or organisational goals and objectives.

\section{Role and purpose of fake news (the how)}

Fake news is the spread of intended information with knowingly provocative and resonating nature. At the same time, the fake itself may contain both false and true (verifiable) information, which can be taken out of context of a specific conversation, discussion or speech. Purposes of fake news are varied and situational, they can include damaging the brand and reputational appeal (therefore potentially crippling the perceived legitimacy and credibility) of a person, subject or object. The aim of fake news is to stir a buzz around a bogus newsworthy event which is created by spreading knowingly provocative information with the desired behaviour (e.g., changing voting patterns) (MacLeod, 2019). Egelhofer and Lechler (2019), Egelhofer et al. (2020) delineate this difference in purpose as fake news as a genre (deceptive information) and fake news as a label (to inflict reputational harm). Various interpretations and applications of the practical role of fake news are suggested by other researchers using diverse focus on activity and outcome.

Differently, other scholars (Bakir \& McStay, 2018; Cooke, 2020; Rini, 2017; Tandoc et al., 2018; Van Heekeren, 2020) state that the two primary motivations for producing and disseminating fake news are financial profit (converting clicks to advertising revenue) and ideological influence (promoting a particular person or set of ideas and/or undermining an opponent). Certainly, researchers have identified the role and invocation of fake news as defining the enemy ideological 'other' in confrontational political and geopolitical discourse (Meeks, 2020; Ross \& Rivers, 2018; van der Linden et al., 2020). This also demonstrates the role and application of the term fake news as a slogan (Meeks, 2020), which carries a potentially powerful emotional rhetorical priming and mobilising effect on target audiences.

Due to the multivariate applications and invocations of the term fake news, some scholars understand the role of fake news as a floating signifier. That is, as an important component of political (and geopolitical) struggles, fake 
news is used to attack and smear an opponent and thereby delegitimise them in the public arena (if believed by the audience). Therefore, actors involved in political conflicts and contests use fake news as a reputational signifier in order to demonstrate and generate (negatively) an image of an ideal society and its proper structure (Farkas \& Schou, 2018). Floating signifiers are used as a means of constructing political identities, conflicts and antagonisms between opposing political projects and groups engaged in a hegemonic struggle (Farkas \& Schou, 2018). This explanation certainly expresses good explanation value as to the evolving nature of the definition and application of fake news, instead of being caught in an endless debate as to what is the truth or not, places the phenomenon within the sphere of information warfare.

The roles of actors vary and depend on the perspective and position of the observer. Research conducted by Al-Rawi (2019) on discourses of fake news in mainstream media versus social media revealed that social media news references on fake news were mostly connected with the alleged bias of mainstream media. On the other hand, mainstream media discourses on fake news concerns social media's negative role in spreading misinformation. Not surprisingly, some researchers conclude that fake news 'is a politicised term where conversations overshadowed logical and important discussions of the term' (Brummette et al., 2018). Fake news has become an object of fear and wonder, owing to the inherent contradictions found in its presumed or assumed ability to penetrate and radically alter the information domain. This is in part fact, but also possessing a large degree of fiction.

The key task of fake news is to seize information agenda and grasp attention, so that the contents of such a fake become topical idea, for a certain period, which captures consciousness of a person influenced by the fake news. Therefore, some researchers say that one of the roles of fake news is setting a news agenda (Yee, 2017). Despite dire warnings of the power of fake news to deceive an audience, recent research indicates that fake news may in fact have limited audience effects beyond increasing beliefs in false claims (Guess et al., 2020). Research conducted in Singapore implies that many people would simply ignore fake news posts that they encounter on social media (Tandoc et al., 2020). Other research suggests that fake news is not unique and powerful in an agenda setting role, playing a much more modest role of adding some further 'noise' to an already sensationalised news environment (Guo \& Vargo, 2020; Vargo et al., 2018). Interestingly, in the wake of the drama created by the 2016 US Presidential Election, the 'fake news epidemic' was blamed on the platforms that enabled the sharing of content (Papanastasiou, 2020; Tandoc et al., 2020), rather than those 
producing the fake news content. There are a variety of roles and purposes that fake news can play in the information and cognitive domains, which is dependent upon the case specific individual or organisational aims and goals. In an overview of this section, fake news is intended to serve a particular operational purpose, therefore the informational programme needs to align with the defined individual or organisational objectives, which is the basis for driving psychological motivations.

\section{Motivations for believing or using fake news (the why)}

Waisbord (2018) notes that 'conventional notions of news and truth that ground standard journalistic practice are harder to achieve and maintain amid the destabilisation of the past hierarchical order'. His logic goes on to propose that 'fake news is indicative of the contested position of news and the dynamics of belief formation in contemporary societies. It is symptomatic of the collapse of the old news order and the chaos of contemporary public communication'. There are a wide range of actors and motivations for engaging in fake news production and dissemination.

The battle for the public mind has gained new dimensions. As pieces of propaganda, fake news is not only produced by states, it may be connected with new developments that perfected and profited from propaganda and misinformation. Enterprising actors full of business imagination reportedly made healthy profits by churning out imaginary news that tapped the naivet of US voters. Ordinary citizens contribute to misinformation by curating and sharing trash information (Waisbord, 2018).

Thus, an underlying factor for the use of fake news is the presence of competition and conflict, especially in an already polarised social, political and economic environment. Such an environment creates both opportunities and threats for actors that occupy these spaces of conflict. Newspapers see a few threats in fake news and accordingly assign the blame. A problematic initial hurdle, even though they spend a lot of time and space to discussing fake news, they have trouble in defining it. Fake news is seen as a serious social problem and social media phenomenon that thrives in a politically polarised society, assisted by social media platforms and driven by economic considerations. It is also considered an economic competitor to an already financially stressed mass media industry as well as a means of de-legitimising the journalism profession (Schapals, 2018; Tandoc et al., 2019). These aspects represent serious challenges and risks for mass media as they seek to adapt from analogue journalism to include digital journalism in the midst of a cultural and identity transformation that affects public perception and opinion. 
There is a very noticeable decline in the level of public trust in theinstitutions of the press and democratic governments, which were believed to be intransparent or accountable, within a rapidly polarising and partisan political environment (Bergström \& Jervelycke Belfrage, 2018; Cheng \& Chen, 2020; Freelon \& Wells, 2020; Morgan, 2018; Potthast et al., 2017; Wagner \& Boczkowski, 2019). This can create a sense of alienation and cynicism among individuals towards the mainstream (Balmas, 2014). As such, fake news has been deemed to be a national security issue owing to the assumption of it undermining the foundations of the nation state (Haciyakupoglu et al., 2018; Roozenbeek \& van der Linden, 2019; Schaewitz et al., 2020). Ironically, exposure to elite discussions on fake news may influence the perception and lower individuals' trust in media and lead them to identify real news less accurately (Van Duyn \& Collier, 2019). This lack of trust, especially in mainstream news sources, is evident in patterns of perception and opinion concerning the production and dissemination of digital news product. This can lead to motivation in seeking alternative views and seeking validation of the credibility of these sources (Fletcher \& Park, 2017; Kiousis, 2001; Kleis Nielsen \& Graves, 2017). In the digital environment, clearly defined and trusted opinion leaders are essential in the trusting and sharing of news within social media networks, which are critical elements for following news developments (Bergström \& Jervelycke Belfrage, 2018). In some circumstances, the highly selective process of news searching and consumption on social media platforms supports the development or filter bubbles and echo chambers that confirm and do not challenge world views, which applies to both audiences and journalists (Albright, 2017; Bakir \& McStay, 2018; Cheng \& Chen, 2020; Cooke, 2020; Gelfert, 2018; Klein \& Wueller, 2017). Therefore, the transmission of fake news is facilitated when it is deemed as being individually reasonable by the audience (Rini, 2017). The effects of confirmation bias exert an effect upon the audience and user's actions, being more likely to read, like, comment and share articles that they agree with (Kim \& Dennis, 2019; Oyserman \& Dawson, 2020; Schaewitz et al., 2020; Valenzuela et al., 2019; Verma et al., 2017, 2018). Within the frame of assessing the size and nature of the fake news audience, Nelson and Taneja (2018) state that 'the audience for fake news was still both small and disloyal'.

The described situation is held as being responsible for creating an environment that is facilitating the existence and spread of fake news. One line of academic thought is the product of a specific group of news consumers who function as activists. In particular, due to a lack of knowledge and the issuance of negative individuals or groups who adhere to strongly felt perceptions are 
motivated to actively communicate their worldview, especially via digital media, in order to influence and persuade others of their 'truth'. The motivation is the social amplification effects of fake news (Krishna, 2017). Albright (2017) notes that social interaction is key to understanding the fake news debate. He suggests reconstructing how audience expresses sentiment around news developments. However, such conclusions can be problematic given the nature of the cognitive domain in terms of defining 'truth' and 'objectivity', which is a very subjective matter. Other studies suggest that the influence of 'incorrect' information cannot simply be undone by pointing out that the information was incorrect (De Keersmaeker \& Roets, 2017). It also ignores the role of mainstream politics and media in the production and dissemination of fake news.

Wahutu (2019) calls for the need to pay attention to official sources as originating sources of fake news, especially during periods of political tension or contestation, which creates the motivation for vested interests to employ fake news tactics for advantage or gain. The uncritical role of mainstream journalism in the dissemination of mainstream political messages has, as a consequence, exacerbated the problem of fake news. Furthermore, the 'discourses about fake news' are based within the premise of 'an informational moral panic' (Wahutu, 2019). Some recent critical research reflects this aspect of self-examination.

Fake news web-sites appear to feed off of the sensational, and there is no lack of such stories during this election [2016 US presidential]. Perhaps, the real concern is not necessarily the growth of fake news web-sites, but rather how accurately and objectively 'real news' depicts the political landscape of the United States (Guo \& Vargo, 2020).

This specific situation can make it difficult for the audience to distinguish the different genres of news, which has the additional effect of further delegitimising the news media further. Comparative media research on the existence and spread of fake news suggests that 'when leading news outlets fail simultaneously, social and alternative $\langle\ldots\rangle$, can replace them as the main information source' (Humprecht, 2019). The situation seems to be best explained within the theoretical framework of a crisis, ${ }^{4}$ where this is simultaneously occurring in the physical domain and the informational domain. Every crisis event goes along with informational flows that define perceptions and opinions formed in the

${ }^{4}$ For the purposes of this paper, a crisis is understood as being the simultaneous presence of 1) a threat to values, 2) unpredictability and 3) time constraint (the longer the event continues the more damage is inflicted). See for example: BOIN, A., T'HART, P., STERN, E., \& SUNDELIUS, B. (2005). The politics of crisis management: Public leadership under pressure. New York, Cambridge University Press. 
cognitive domain. This creates a competition among the stakeholders to control those informational flows in order to try and control the construction orthodoxy of 'reality' and 'truth' that defines the physical domain.

\section{Conclusion}

Fake news is a complex and heated academic issue as well as a practitioner and policy maker debate on its operational use. There is a very broad discussion with seemingly few points of agreement on the surface, a debate that spans numerous academic disciplines, each with their own specific points of focus and attention. This present article has been a modest attempt to try and illustrate as many of these aspects as possible. In the introduction of this paper, a research question was posed: what are the informational and cognitive conditions that support a fake news environment? It was posed to attempt a tentative taxonomy of environmental (informational and cognitive) specifics that facilitate the creation and use of fake news as a concept and practice.

Fake news is both a tool of deceptive persuasive communication and an accusation that is intended to undermine the credibility and effectiveness of a competing actor as a communicator. As a form of persuasive communication, fake news already exhibits some of the narratives of older forms of persuasive communication, such as propaganda. It has become a 'dirty word' owing to the deceptive and manipulative reputation and practice. Therefore, being more commonly seen is the narrative that it is not something that 'we' do, but rather an opponent does.

In the perspective and lens as a floating signifier, fake news is brought within the framework of information warfare. It is the discursive exercise of seeking to shape how an ideal (subjectively) version of society can be imagined, communicated by the actors to the target audience - a highly symbolic representation of the physical domain that is transmitted through the information domain to influence and shape the cognitive domain. Fake news can be used defensively by the incumbent hegemonic power to ward off a challenger and retain its position as a leader. However, fake news can be used offensively by the challenger to unseat the leader and take their position of power. This concerns the acquisition or detraction of social and/or political capital as a means of projecting legitimacy or de-legitimacy in a contest for persuasion and influence.

This only leaves the creation of a tentative taxonomy of fake news, which is based on the sum of knowledge contained in this article, a means to provide a quick reference and guide to better understanding this phenomenon. The 
following factors and aspects, in no particular order of appearance, are often associated in defining the meaning, nature and presence of fake news:

- Intentional and deliberate communication, it is a form of organised persuasive communication, which can overlap within the field of information warfare;

- Fake news must serve a specific organisational or individual goal-social, economic, political, etc.;

- Competition for influence, power or control in its various forms can drive the use of fake news;

- Consciously seeks to deceive a target audience, rather than the entertain or distract function of satire;

- Seeks to influence the cognitive domain through emotional and symbolic representations of the physical domain through the information domain;

- Fake news as a term (buzzword) is new, but it is not new as a practice;

- Difference between 'old' fake news and the current form is the immediacy and reach that has been enabled by digital communication technologies;

- There is a dichotomy of use and application of fake news, as a genre of deceptive communication and as a label intended for character assassination and reputational attack;

- Fake news acts as a floating signifier of individual and group identity, distinguishing the 'In' and 'Out' groups from each other in a simplified binary fashion;

- Fake news is enabled in moments of crisis, especially where the decline of one political or geopolitical hegemony encourages challengers, which creates a crisis of information and communication for hearts, minds and the perception of legitimacy;

- Seeks to gain as much attention and exposure to the widest audience as possible, often relying on symbolic and emotional means to quickly prime and mobilise the audience;

- Fake news actors are not restricted to 'right-wing fringe groups' and other such non-mainstream actors, but can be anyone with an intention to deliberately deceive, including professional journalists;

- Fake news as a cognitive construct is contextual and is in the eye of the beholder.

In way of a parting note, the academic profession requires and prides itself on the precision of definition, the clarity it brings to the study, and understanding of elements in our world. This is a completely logical and understandable basis for those that are criticising the chaos and lack of clarity present in the term 'fake 
news'. However, 'fake news' is a familiar term and has a wider interpretation in our society and this needs to be recognised. The term should be kept, in spite of its various and obvious flaws, in order for academia to be part of the critical debates in the society, rather than being apart from them in our Ivory Towers.

\section{References}

ALBERTS, D. S., GARSTKA, J. J., HAYES, R. E., \& SIGNORI, D. A. (2001). Understanding information age warfare. Washington DC, CCRP Publication Series.

ALBRIGHT, J. (2017). Welcome to the era of fake news. Media and Communication, 5(2), pp. 87-89.

AL-RAWI, A. (2019). Gatekeeping fake news discourses on mainstream media versus social media. Social Science Computer Review, 37(6), pp. 687-704.

BAKIR, V., HERRING, E., MILLER, D., \& ROBINSON, P. (2019). Organised persuasive communication: A new conceptual framework for research on public relations, propaganda and promotional culture. Critical Sociology, 45(3), pp. 311-328.

BAKIR, V. \& MCSTAY, A. (2018). Fake news and the economy of emotions. Digital Journalism, 6(2), pp. 154-175.

BALMAS, M. (2014). When fake news becomes real: Combined exposure to multiple news sources and political attitudes of inefficacy, alienation, and cynicism. Communication Research, 41(3), pp. 430-454.

BERGSTRÖM, A. \& JERVELYCKE BELFRAGE, M. (2018). News in social media: Incidental consumption and role of opinion leaders. Digital Journalism, 6(5), pp. 583-598.

BORÉUS, K. \& BERGSTRÖM, G. (2017). Analysing text and discourse: Eight approaches for the social sciences. Thousand Oaks (CA), Sage Publishing.

BRENNEN, B. (2017). Making sense of lies, deceptive propaganda, and fake news. Journal of Media Ethics, 32(3), pp. 179-181.

BRUMMETTE, J., DISTASO, M., VAFEIADIS, M., \& MESSNER, M. (2018). Read all about it: The politicisation of 'fake news' on Twitter. Journalism \& Mass Communication Quarterly, 95(2), pp. 497-517.

BURKHARDT, J. M. (2017). History of fake news. Library Technology Reports, 53(8), pp. 5-9.

CARVALHO, L. DE L. (2017). The case against fake news gatekeeping by social networks. SSRN, 1st November, 2017. Available from: https://ssrn.com/ abstract $=3060686$

CHENG, Y. \& CHEN, Z. F. (2020). The influence of presumed fake news influence: Examining public support for corporate corrective response, media 
literacy interventions, and governmental regulation. Mass Communication and Society, 23(5), pp. 705-729. DOI: 10.1080/15205436.2020.1750656.

COOKE, N. A. (2017). Post-truth, truthiness, and alternative facts: Information behaviour and critical information consumption for a new age. The Library Quarterly: Information Community Policy, 87(3), pp. 211-221.

DE KEERSMAECKER, J. \& ROETS, A. (2017). 'Fake news': Incorrect, but hard to correct. The role of cognitive ability on the impact of false information and social impressions. Intelligence, 65, pp. 107-110.

DREXL, J. (2019). Economic efficiency versus democracy: On the potential role of competition policy in regulating digital markets in times of post-truth politics. In: D. Gerard \& I. Lianos, Reconciling efficiency and equity: A global challenge for competition policy. Cambridge, Cambridge University Press.

EGELHOFER, J. L., AALDERING, L., EBERL, J.-M., GALYGA, S., \& LECHELER, S. (2020). From novelty to normalisation? How journalists use the term 'fake news' in their reporting. Journalism Studies, 21(10), pp. 1323-1343. DOI: 10.1080/146167 0X.2020.17455566.

EGELHOFER, J. L. \& LECHELER, S. (2019). Fake news as a two-dimensional phenomenon: A framework and research agenda. Annals of the International Communication Association, 43(2), pp. 97-116.

FARKAS, J. \& SCHOU, J. (2018). Fake news as a floating signifier: Hegemony, antagonism and the politics of falsehood. Javnost - The Public, 25(3), pp. 298-314.

FLETCHER, R. \& PARK, S. (2017). The impact of trust in the news media on online news consumption and participation. Digital Journalism, 5(10), pp. 12811299.

FREELON, D. \& WELLS, C. (2020). Disinformation as political communication. Political Communication, 37(2), pp. 145-156.

GAVRA, D. \& NAUMENKO, K. (2020). Russian humanitarian mission in Bergamo in the fight against the coronavirus pandemic: Reflection in the Italian media discourse. Vestnik Moskovskogo Universiteta. Seriya 10. Zhurnalistika, 6, pp. 77-107. DOI: 10.30547/vestnik.journ.6.2020.77107

GELFERT, A. (2018). Fake news: A definition. Informal Logic, 38(1), pp. 84-117.

GELMAN, S. A. (1996). Concepts and theories. In: Handbook of perceptual and cognitive development, San Diego, Academic Press Inc.

GUESS, A. M., LOCKETT, D., LYONS, B., MONTGOMERY, J. M., NYHAN, B., \& REIFLER, J. (2020). 'Fake news' may have limited effects beyond increasing beliefs in false claims. Harvard Kennedy School, 14th January, 2020. Available from: https://misinforeview.hks.harvard.edu/article/fake-news-limited-effects-onpolitical-participation/. 
GUO, L. \& VARGO, C. (2020). 'Fake news' and emerging online ecosystem: An integrated intermedia agenda-setting analysis of the 2016 U.S. presidential election. Communication Research, 47(2), pp. 178-200.

HA, L., PEREZ, L. A., \& RAY, R. (2019). Mapping recent development in scholarship on fake news and misinformation, 2008-2017: Disciplinary contribution, topics, and impact. American Behavioural Scientist, 65(2), pp. 290-315. DOI: $10.1177 / 0002764219869402$.

HACIYAKUPOGLU, G., HUI, J. Y., LEONG, D., \& RAHMAN, M. F. B. A. (2018). Countering fake news: A survey of recent global initiatives. Policy report. Singapore, S. Rajaratnam School of International Studies.

HARCUP, T. \& O'NEILL, D. (2017). What is news? News values revisited (again). Journalism Studies, 18(12), pp. 1470-1488.

HOLAN, A. (2017). The media's definition of fake news vs. Donald Trump's. First Amendment Law Review, 16, pp. 121-128.

HUMPRECHT, E. (2019). Where 'fake news' flourishes: A comparison across four Western democracies. Information, Communication \& Society, 23(13), pp. 1973-1988.

JANKOWSKI, N. W. (2018). Researching fake news: A selective examination of empirical studies. Javnost - The Public, 25(1-2), pp. 248-255.

KAZUN, A. P. \& KAZUN, A. D. (2020). Populism, political personalisation and the attention of leading print media to foreign leaders in the G20. Vestnik Moskovskogo Universiteta. Seriya 10. Zhurnalistika, 5, pp. 77-97. DOI: 10.30547/ vestnik.journ.5.2020.7797

KIM, A. \& DENNIS, A. R. (2019). Says who? The effects of presentation format and source rating on fake news in social media. MIS Quarterly, 43(3), pp. 10251039.

KIOUSIS, S. (2001). Public trust or mistrust? Perceptions of media credibility in the information age. Mass Communication \& Society, 4(4), pp. 381-403.

KLEIN, D. O. \& WUELLER, J. R. (2017). Fake news: A legal perspective. Journal of Internet Law, 20(10), pp. 5-13.

NIELSEN, R. K. \& GRAVES, L. (2017). 'News you don't believe': Audience perspectives on fake news. Factsheet. University of Oxford, Reuters Institute.

KOVACH, B. \& ROSENSTIEL, T. (2007). The elements of journalism: What newspeople should know and the public should expect. New York, Three Rivers Press.

KRISHNA, A. (2017). Motivation with misinformation: Conceptualising lacuna individuals and publics as knowledge-deficient, issue-negative activists. Journal of Public Relations Research, 29(4), pp. 176-193. 
LAZER, D. M. J., BAUM, M. A., BENKLER, Y., BERINSKY, A. J., GREENHILL, K. M., MENCZER, F., METZGER, M. J., NYHAN, B., PENNYCOOK, G., ROTHSCHILD, D., SCHUDSON, M., SLOMAN, S. A., SUNSTEIN, C. R., THORSON, E. A., WATTS, D. J., \& ZITTRAIN, J. L. (2018). The science of fake news: Addressing fake news requires a multidisciplinary effort. Science, 359(6380), pp. 1094-1096.

MCNAIR, B. (2004). The sociology of journalism. London, Arnold Publishers.

MEEKS, L. (2020). Defining the enemy: How Donald Trump frames the news media. Journalism \& Mass Communication Quarterly, 97(1), pp. 211-234.

METAXA-KAKAVOULI, D. \& TORRES-ECHEVERRY, N. (2017). Google's role in spreading fake news and misinformation. SSRN, 5th November, 2017. Available from: https://ssrn.com/abstract $=3062984$

MORGAN, S. (2018). Fake news, disinformation, manipulation and online tactics to undermine democracy. Journal of Cyber Policy, 3(1), pp. 39-43.

MOULD, T. (2018). Introduction to the special issue on fake news: Definitions and approaches. The Journal of American Folklore, 131(522), pp. 371-378.

NELSON, J. L. \& TANEJA, H. (2018). The small, disloyal fake news audience. The role of audience availability in fake news consumption. New Media \& Society, 20(10), pp. 3720-3737.

OYSERMAN, D. \& DAWSON, A. (2020). Your fake news our facts: Identity based motivation shapes what we believe, share, and accept. In: R. Greifenender, M. Jaffe, E. J. Newman, \& N. Schwarz, The psychology of fake news: Accepting, sharing, and correcting misinformation. London, Routledge.

PAPANASTASIOU, Y. (2020). Fake news propagation and detection: A sequential model. Management Science, 66(5), pp. 1826-1846.

PENNYCOOK, G., CANNON, T., \& RAND, D. G. (2018). Prior exposure increases perceived accuracy of fake news. Journal of Experimental Psychology, 147(12), pp. 1865-1880.

POTTHAST, M., KIESEL, J., REINARTZ, K., BEVENDORFF, J., \& STEIN, B. (2017). A stylometric inquiry into hyper partisan and fake news. Available from: https://arxiv.org/abs/1702.05638

Propaganda in the information age: Still manufacturing consent (2019). Edited London, Routledge.

RINI, R. (2017). Fake news and partisan epistemology. Kennedy Institute of Ethics Journal, 27(2), pp. E43-E64.

ROOZENBEEK, J. \& VAN DER LINDEN, S. (2019). The fake news game: Actively inoculating against the risk of misinformation. Journal of Risk Research, 22(5), pp. 570-580. 
ROSS, A. S. \& RIVERS, D. J. (2018). Discursive deflection: Accusation of 'fake news' and the spread of mis- and disinformation in the tweets of President Trump. Social Media + Society, 4(2).

SCHAEWITZ, L., KLUCK, J. P., KLÖSTERS, L., \& KRÄMER, N. C. (2020). When disinformation is (in)credible? Experimental findings on message characteristics and individual differences. Mass Communication and Society, 23(4), pp. 484-509. DOI: $10.1080 / 15205436.2020 .1716983$.

SCHAPALS, A. K. (2018). Fake news: Australian and British journalists' role perceptions in an era of 'alternative facts'. Journalism Practice, 12(8), pp. 976-985.

SCHNELLENBACH, J. (2018). On the behavioural political economy of regulating fake news. ORDO: Jahrbuch für die Ordnung von Wirtschaft und Gesellschaft, 68(1), pp. 159-178.

SHU, K., SLIVA, A., WANG, S., TANG, J., \& LIU, H. (2017). Fake news detection on social media: A data mining perspective. SIGKDD Explorations, 19(1), pp. 22-36.

SIMONS, G. (2017). Fake news: As the problem or a symptom of a deeper problem? Obraz, 4(26), pp. 33-44.

SZEMAN, I. \& KAPOSY, T. (2011). Cultural theory: An anthology. Hoboken (NJ), Wiley-Blackwell.

TANDOC, JR., EDSON, C., LIM, D., \& LING, R. (2020). Diffusion of disinformation: How social media users respond to fake news and why. Journalism, 21(3), pp. 381-398.

TANDOC, JR., EDSON, C., JENKINS, J., \& CRAFT, S. (2019). Fake news as a critical incident in journalism. Journalism Practice, 13(6), pp. 673-689.

TANDOC, JR., EDSON, C., LIM, Z. W., \& LING, R. (2018). Defining 'fake news': A typology of scholarly definitions. Digital Journalism, 6(2), pp. 137-153.

VALENZUELA, S., HALPERN, D., KATZ, J. E., \& MIRANDA, J. P. (2019). The paradox of participation versus misinformation: Social media, political engagement, and the spread of misinformation. Digital Journalism, 7(6), pp. 802-823.

VAN DER LINDEN, S., PANAGOPOULOS, C., \& ROOZENBEEK, J. (2020). You are fake news: Political bias in perceptions of fake news. Media, Culture \& Society, 42(3), pp. 460-470.

VAN DUYN, E. \& COLLIER, J. (2019). Priming and fake news: The effects of elite discourse on evaluations of news media. Mass Communication and Society, 22(1), pp. 29-48.

VAN HEEKEREN, M. (2020). The curative effect of social media on fake news: A historical re-evaluation. Journalism Studies, 21(3), pp. 306-318.

VARGO, C. J., LEI GUO, L., \& AMAZEEN, M. A. (2018). The agenda-setting power of fake news: A big data analysis of the online media landscape from 2014 to 2016. New Media \& Society, 20(5), pp. 2028-2049. 
VERMA, N., KOLTAI, K. S., \& FLEISCHMANN, K. R. (2017). Human values and trust in scientific journals, the mainstream media and fake news. 8oth Annual Meeting of the Association for Information Science \& Technology, Washington DC, pp. 426-435.

VERMA, N., KOLTAI, K. S., \& FLEISCHMANN, K. R. (2018). Demographic factors and trust in different news sources. ASIS\&T Annual Meeting, 55(1), pp. 524-533.

VERSTRAETE, M., BAMBAUER, D. E., \& BAMBAUER, J. R. (2017). Identifying and countering fake news. Arizona Legal Studies Discussion Paper, 17-15. Available from: https://ssrn.com/abstract $=3007971$

WAHUTU, J. S. (2019). Fake news and journalistic rules of the game. African Journalism Studies, 40(4), pp. 13-26. DOI: 10.1080/23743670.2019.1628794.

WAISBORD, S. (2018). Truth is what happens to news: On journalism, fake news, and post-truth. Journalism Studies, 19(13), pp. 1866-1878.

WAGNER, M. C. \& BOCZKOWSKI, P. J. (2019). The reception of fake news: The interpretations and practices that shape the consumption of perceived misinformation. Digital Journalism, 7(7), pp. 870-885.

WARD, S. J. A. (2014). Radical media ethics: Responding to a revolution. Nordicom Review, 35, pp. 45-52.

YEE, A. (2017). Post-truth politics and fake news in Asia. Global Asia, 12(2), pp. 67-71. 